\title{
Kinetics and statistical analysis of the bio- stimulating effects of goat litter in crude oil biodegradation process
}

\author{
Kingsley Amechi Ani ${ }^{* *}$ and Emmanuel Chibundo Chukwuma²
}

\begin{abstract}
Background: The kinetics and statistical analysis of crude oil (CO) degradation in CO-contaminated soil (COCS) using goat litter $(\mathrm{GL})$ were investigated. The data obtained from the CO degradation process was fitted to the firstand second-order kinetic models. The effects of process parameters such as temperature and the initial CO concentrations on the CO degradation process were also investigated. The one-way ANOVA and Turkey's post-hoc analysis were also used to study the statistical significance of the process parameters on the CO degradation process.

Results: The microbial count showed that the GL contained a total viable count (TVC), coliform, and mold counts of $2.6 \times 10^{7} \mathrm{CFUg}^{-1}, 2.6 \times 10^{7} \mathrm{CFUg}^{-1}$, and $6.9 \times 10^{3} \mathrm{CFUg}^{-1}$, respectively. The error and linear regression analysis between experimental and model-predicted values revealed that the first-order kinetic model gave a better explanation of the CO degradation process. The rejection of the null hypothesis was evident from one-way ANOVA and Turkey's post-hoc analysis as the $P$ values at a temperature of $30^{\circ} \mathrm{C}$ and initial $\mathrm{CO}$ concentrations of $70 \mathrm{gL}^{-1}$ and $90 \mathrm{gL}^{-1}$ were less than the significant level of 0.05 . Notable organic nutrients in the $\mathrm{GL}$ which were beneficial in the COCS treatment process as indicated by the Fourier-transform infrared spectrophotometer (FTIR) analysis were phosphorous and nitrogen.
\end{abstract}

Conclusions: It may be concluded that GL could be used as an effective organic treatment for COCS at CO initial concentrations of 70 and $90 \mathrm{gL}^{-1}$ and a temperature of $30^{\circ} \mathrm{C}$.

Keywords: Crude oil, Goat litter, First-order, Second-order, One-way ANOVA, Turkey's post-hoc

\section{Background}

The activities of humans in the exploration, refining, transportation, storage, and usage of crude oil (CO) are some of the many ways by which $\mathrm{CO}$ is steadily being introduced into the environment. $\mathrm{CO}$ in its refined state could be used in the generation of energy and production of valuable industrial raw materials. In recent years, the spillage of $\mathrm{CO}$ and its refined products into the environment has been a source of environmental concern as the available arable soil is steadily being contaminated $[1,2]$.

\footnotetext{
*Correspondence: anikingsley16@yahoo.com

'Department of Chemical Engineering, Faculty of Engineering, Nnamdi

Azikiwe University, Awka, Anambra State, Nigeria

Full list of author information is available at the end of the article
}

There have been lots of researches and innovations in the area of environmental remediation due to the increasing demands from public and government regulations on the need to scale down $\mathrm{CO}$ spill within the environments. A number of conventional technologies, which have been used for the remediation of hydrocarbon contaminated environments, include soil flushing, solvent extraction, electro-kinetic remediation, photo-catalytic degradation, etc. [3, 4]. These conventional technologies are associated with high capital intensive, ecological unacceptable, and might not viable for developing nations like Nigeria.

However, microbial degradation of hydrocarbon has begun to gain wider acceptance as an efficient alternative for hydrocarbon degradation due to its simplicity and 
environmentally acceptable $[5,6]$. The different catabolic pathways developed by microorganisms enable them to efficiently utilize the insoluble hydrocarbon. One of the pathways developed by microorganism includes the high affinity to hydrophobic surfaces, which enable them to directly absorb and utilize the hydrocarbon contaminant $[7,8]$. Also, during microbial metabolisms, enzymes such as dioxygenases, catalases, and peroxidases are released [9]. These enzymes could oxidize and subsequently transform the hydrocarbon contaminant into less toxic compounds [10].

Bio-stimulation, an aspect of bioremediation entails the addition of organic materials rich in the microbial population, micro- and macronutrients in the contaminated soil [11]. The advantage of bio-stimulation is that the bioremediation process will be carried out by both the microbes in the added organic materials and the contaminated soil [2]. Furthermore, the added organic materials during bio-stimulation could improve the fertility of the contaminated soil $[1,12,13]$.

In this present study, goat litter (GL) was used as biostimulating organic material to study the kinetics and statistical analysis of $\mathrm{CO}$ degradation. The application of GL as organic material has been known to improve the physicochemical properties of the soil, beneficial to soil microorganism, and enhance the overall fertility of the soil. Awodun et al. [14] reported that GL was better than other livestock manure as its moisture content is much lower, thus leading to a slow dissipation of its nutrients into the soil. Similarly, the neutral $\mathrm{pH}$ of the GL was also found to be conducive for microbial growth and proliferation [14]. However, GL is a major source of nitrogen, phosphorous, potassium, calcium, magnesium, and organic matter, which are necessary for crop production [15].

Accordingly, the objectives of this study were to investigate the kinetics and statistical analysis of $\mathrm{CO}$ degradation in the crude oil-contaminated soil (COCS). The effects of process parameters such as the initial $\mathrm{CO}$ concentrations and temperature were also investigated. The prevalent functional groups in the GL and COCS were also investigated using Fourier transform infrared (FTIR). Furthermore, one-way analysis of variance (ANOVA) and Turkey's post-hoc analysis were used to evaluate the statistically significant $(P<0.05)$ effects of the process parameters on the $\mathrm{CO}$ degradation process.

\section{Methods}

\subsection{Samples collection}

The GL used in this study was collected from a farmhouse located at Ogwofia-Ozom Mgbagbu Owa in Enugu state Nigeria. The GL was air-dried for 2 weeks, ground and passed through 5-mm sieve for homogeneity before use. The $\mathrm{CO}$ was collected from Warri petrochemical refinery in Delta State Nigeria. An agricultural soil with no history of hydrocarbon contamination was collected from the soil science garden of the University of Nigeria Nsukka [16]. The samples were taken to the soil science laboratory of the University of Nigeria Nsukka for further analysis.

\subsection{Preparation of $\mathrm{CO}$ stock solution}

The $\mathrm{CO}$ stock solutions used in this experiment were prepared by weighing out 50,70, and $90 \mathrm{~g}$ of $\mathrm{CO}$ using PCE analytical weighing balance (PCE-6000). Each of the $\mathrm{CO}$ mass samples was dissolved in $1.0 \mathrm{~L}$ of distilled water to give initial $\mathrm{CO}$ concentrations of $50 \mathrm{gL}^{-1}, 70 \mathrm{gL}^{-1}$, and $90 \mathrm{gL}^{-1}$ [16]. The soil was artificially contaminated by spiking the various prepared $\mathrm{CO}$ concentrations on $200 \mathrm{~g}$ of the clean soil sample. The crude oil-contaminated soil (COCS) samples were allowed to stay for 21 days to permit the volatilization and sorption of the $\mathrm{CO}$ into the soil matrix. After 21 days, the COCS was supplemented with $100 \mathrm{~g}$ of GL as bio-stimulating organic material and was designated as (COCS-GL).

\section{$2.3 \mathrm{CO}$ degradation procedure}

The prepared $200 \mathrm{~g}$ of COCS was placed in a plastic container with dimension $6.5 \times 6.5 \times 3.5 \mathrm{~cm}$. Control samples were also prepared with the same quantity of soil and CO concentrations but with no GL [16]. Both the control samples and treated samples were prepared in triplicates, aerated, and mixed properly twice a week. This was to enhance the supply of oxygen, which was required to maintain microbial respiration during the $\mathrm{CO}$ degradation process $[13,17]$. The contaminated soils in the treatment containers were covered with polyethylene foil after mixing to prevent the influence of atmospheric weather conditions [17]. The performance of the process was monitored and samples were collected on the 7, 14, $21,28,35,42,49$, and 56 days of treatment for analysis and also to calculate the percentage $\mathrm{CO}$ degraded in these periods.

\subsection{Determination of $\mathrm{CO}$ percentage degradation}

The solvent extraction procedure of gas chromatography equipped with a splitless injector and flame ionization detector was used to estimate the residual $\mathrm{CO}$ concentrations $[2,12]$. The dried sub-samples were extracted for $2 \mathrm{~h}$ using acetone/dichloromethane $(1: 1 \mathrm{v} / \mathrm{v})$ as the extracting solvent. The solvent was left to evaporate after the extraction process, and the residue (extract) was dissolved in $5 \mathrm{~mL}$ dichloromethane. The temperature range was maintained at $40^{\circ} \mathrm{C}$ for $2 \mathrm{~min}$ before increasing it to $320^{\circ} \mathrm{C}$ at a rate of $7{ }^{\circ} \mathrm{C} / \mathrm{min}$. The rate was increased to $20^{\circ} \mathrm{C} / \mathrm{min}$ until the temperature reached $400^{\circ} \mathrm{C}$, after which, the temperature was constant for $10 \mathrm{~min}$. The 
recovery of $\mathrm{CO}$ using this method was higher than $68 \%$. The $\mathrm{CO}$ concentrations were determined after proper calibration of the method with standard $\mathrm{CO}$ samples at different concentrations. The percentage of $\mathrm{CO}$ degraded was calculated using the expression in Eq. 1:

$$
\% \mathrm{CO} \text { degradation }=\frac{\text { initial CO concentration }- \text { final } \mathrm{CO} \text { concentration }}{\text { initial } \mathrm{CO} \text { concentration }} \times 100
$$

Where; the initial $\mathrm{CO}$ concentration $\left(\mathrm{gL}^{-1}\right)$ is at time $=0$, and the final $\mathrm{CO}$ concentration $\left(\mathrm{gL}^{-1}\right)$ is at time $=t$

\subsection{Microbial count}

A total of $1 \mathrm{~g}$ of the samples (GL and COCS) was placed in a test tube containing $9 \mathrm{~mL}$ Ringer solution. The Ringer solution had the following compositions $(\mathrm{g} / \mathrm{mL})$; $6.5 \mathrm{NaCl}, 0.25 \mathrm{CaCl}_{2}$, and $0.2 \mathrm{NaHCO}_{3}$. The mixtures were mixed thoroughly at $150 \mathrm{rpm}$ on a rotary shaker. The mixture was further diluted by transferring $1 \mathrm{~mL}$ into three test tubes containing a $9 \mathrm{~mL}$ Ringer solution using a sterile pipette. Thereafter, $0.1 \mathrm{~mL}$ of the diluted solution was transferred from each dilution test tube into three sterile Petri dishes using a sterile pipette. For total viable count, (TVC) mold count, and coliform count, $15 \mathrm{~mL}$ of sterile nutrient agar, Sabouraud Dextrose Agar (SDA) and sterile violet red bile agar, respectively were poured into each of the Petri dishes and gently rotated on the table to mix. The nutrient agar, SDA, and sterile violet red bile agar in the Petri dishes were allowed to gel for $10 \mathrm{~min}$ before sealing and were incubated in an inverted position at $37^{\circ} \mathrm{C}$ for $24 \mathrm{~h}$. The colonies formed were counted using a Quebec colony counter (Reichert dark field 13332500/13332600) and was expressed as the colony-forming unit per gram $\left(\mathrm{CFUg}^{-1}\right)$.

\subsection{Effect of temperature}

An incubation experiment was set up in a water bath (Stuart SBS40 Shaking water bath) with a temperature regulator and adjustable shaking speed. The water bath platform accommodated four Erlenmeyer flasks of 250 $\mathrm{mL}$. Each of the four flasks contained $100 \mathrm{~g}$ of the COCS-GL. The samples were incubated at $10^{\circ} \mathrm{C}, 20^{\circ} \mathrm{C}$, and $30{ }^{\circ} \mathrm{C}$. The adjustable shaking speed of the water bath was set at $150 \mathrm{rpm}$. A polycarbonate water bath cover was used to cover the water bath in order to prevent heat loss by evaporation in either of the stainless steel interior or from the incubated samples. The water bath was capable of measuring temperatures within the ranges of $10^{\circ} \mathrm{C}$ to $90^{\circ} \mathrm{C}( \pm 0.25)$. The set temperature of the water bath was monitored through the easy to read light-emitting diode (LED) display screen for a contact time of $30 \mathrm{~min}$. The experiments were conducted in triplicates and the statistical mean of the results was recorded.

\subsection{Statistical analysis}

The significant effects of the initial $\mathrm{CO}$ concentration and temperature on $\mathrm{CO}$ degradation were evaluated using one-way ANOVA and Turkey's post-hoc multiple comparisons. This was in order to estimate the variance within and between the group means. The one-way ANOVA and Turkey's post-hoc tests were processed using IBM SPSS (version 22). However, the Turkey's post-hoc was used to predict the honest significant difference that must have existed in distance between two groups mean. The statistically significant difference between the two group's means was ascertained at $P<$ 0.05 .

\subsection{Error analysis of the first- and second-order kinetic models}

The error functions in Table 1 were employed to evaluate the suitable kinetic model that best describes the experimental data on $\mathrm{CO}$ degradation. The minimization of the fractional error across the entire $\mathrm{CO}$ concentration range was achieved using the average relative error deviation (ARED) $[18,19]$. The root-mean-square error (RMSE) was used to evaluate the residuals errors between the experimental and model-predicted values [20]. The standard error of prediction (SEP) measures the accuracy of the model prediction in comparison with the experimental values (Table 1). The magnitudes of errors between the predicted and experimental values were estimated using the mean absolute error (MAE). The correlation coefficient $\left(R^{2}\right)$ was used to measure how close the data are to the fitted regression line [21]. In summary, the goodness of fit of either model (first- and second-order) was evaluated with higher $R^{2}$ values and lower values of ARED, RMSE, MAE, and SEP [22].

\section{Results}

3.1 Characterizations of the COCS and GL

Figure 1 presents the FTIR spectrum pattern for the COCS. The spectral pattern exhibits thirteen peaks at wavelengths of 4336.12 to $431.10 \mathrm{~cm}^{-1}$. The peaks at

Table 1 Statistical error functions

\begin{tabular}{|c|c|c|}
\hline Error functions & Equations & Refs. \\
\hline ARED & $\frac{1}{n} \sum_{i=1}^{n}\left(\frac{\text { Exp. }_{i-} \text {-Pred }_{. i}}{\text { Exp.i }_{. i}}\right) \times 100$ & [18] \\
\hline RMSE & $\sqrt{\sum_{i=1}^{n}(\text { Exp.i-Pred.i })^{2 / n}}$ & [19] \\
\hline MAE & $\frac{i}{n} \sum_{i=1}^{n}\left(\right.$ Exp. $_{. i}-$ Pred $\left._{. i}\right)$ & [20] \\
\hline SEP & $\frac{\text { RSME }}{\operatorname{Exp}_{. \mathrm{i}}} \times 100$ & [19] \\
\hline \multirow[t]{2}{*}{$R^{2}$} & $\sum_{i=1}^{n}($ pred.i-Exp.i) & [21] \\
\hline & $\sqrt{\sum_{i=1}^{n}(\text { pred.i-Exp.i) })^{2}(\text { pred.i-Exp.i) }}$ & \\
\hline
\end{tabular}




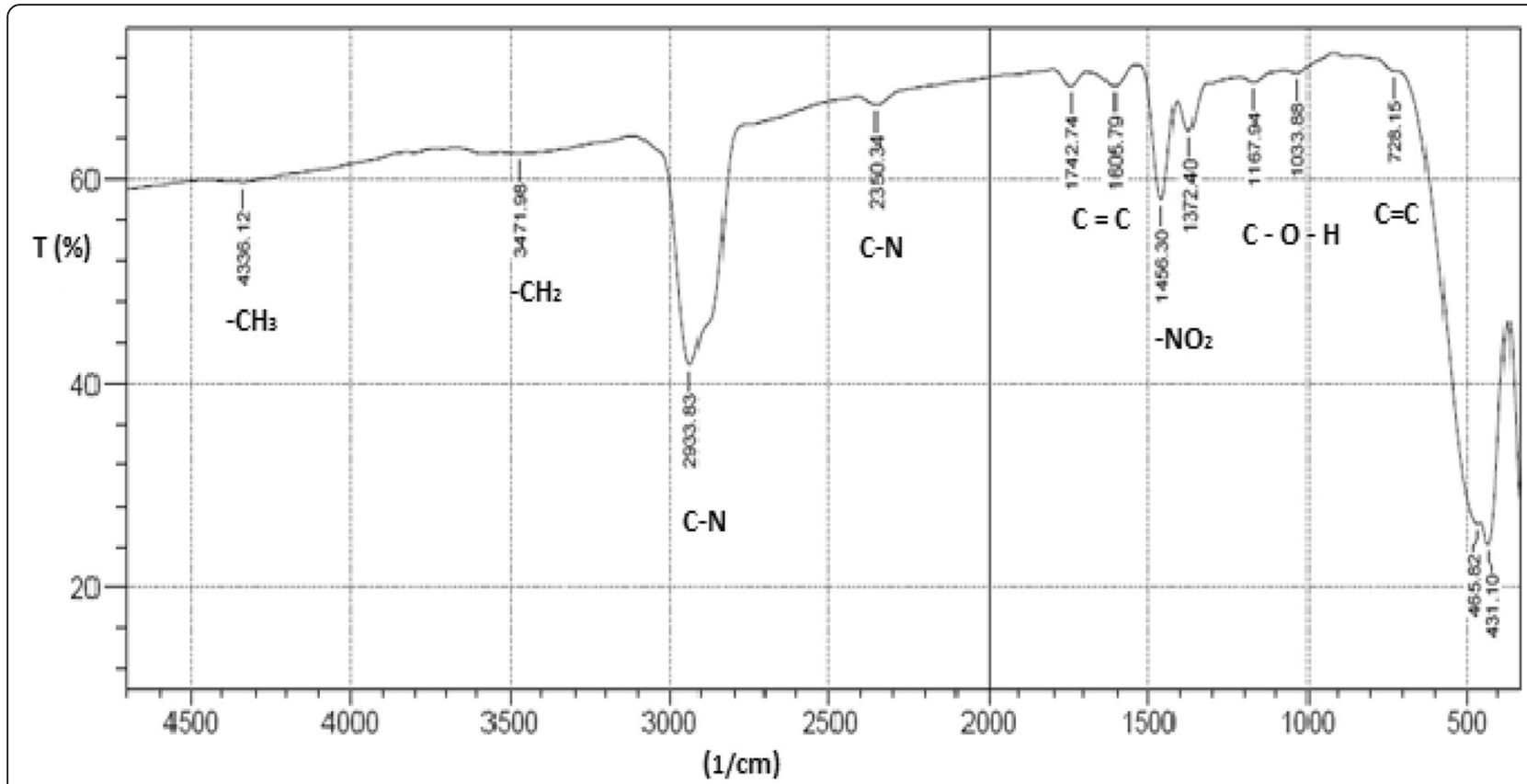

Fig. 1 Fourier transform-infrared spectroscopic analysis for COCS

4336.12 and $3471.98 \mathrm{~cm}^{-1}$ with $47 \%$ and $37 \%$ transmittance, respectively are indicative of alkyl $-\mathrm{CH}_{3}$ and $\mathrm{CH}_{2}$ stretching vibration. The peaks at 2933.83 and $2350.34 \mathrm{~cm}^{-1}$ with $48 \%$ transmittance are characteristics of $\mathrm{C}-\mathrm{N}$ of nitriles (Fig. 1). The peak found at 1605.79 $\mathrm{cm}^{-1}$ with $45 \%$ transmittance is a characteristic of $\mathrm{C}=\mathrm{C}$ stretching of an alkene. The band at $1456.30 \mathrm{~cm}^{-1}$ with $46 \%$ transmittance is a characteristic of $\mathrm{NO}_{2}$ asymmetric stretching. The peak located at $1372.40 \mathrm{~cm}^{-1}$ with $47 \%$ transmittance is a characteristic of $\mathrm{C}-\mathrm{O}-\mathrm{H}$. The peaks

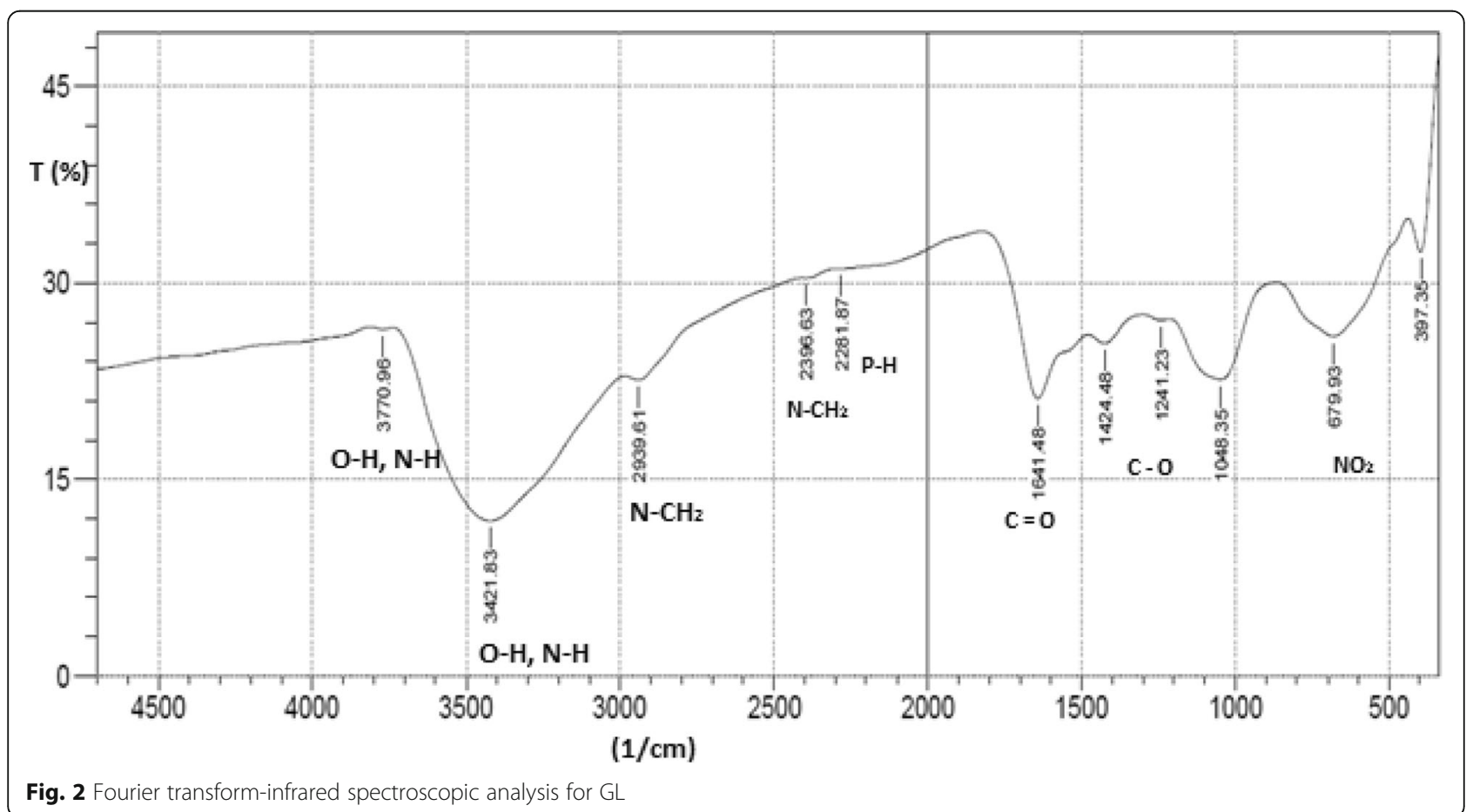

Fig. 2 Fourier transform-infrared spectroscopic analysis for $\mathrm{GL}$ 
Table 2 Microbial count

\begin{tabular}{llll}
\hline Parameters & TVC & Coliform & Mold count \\
\hline & $\left(\mathrm{CFUg}^{-1}\right)$ & $\left(\mathrm{CFUg}^{-1}\right)$ & $\left(\mathrm{CFUg}^{-1}\right)$ \\
GL & $2.6 \pm 0.10 \times 10^{7}$ & $7.8 \pm 0.22 \times 10^{3}$ & $6.9 \pm 1.12 \times 10^{3}$ \\
COCS & $1.1 \pm 2.11 \times 10^{3}$ & $2.1 \pm 0.92 \times 10^{3}$ & $6.3 \pm 0.76 \times 10^{3}$ \\
\hline
\end{tabular}

Values represent \pm standard deviation (SD) of triplicates measurement, TVC is the total viable count in $\mathrm{CFUg}^{-1}$

found at 1033.88 and $728.16 \mathrm{~cm}^{-1}$ with $46 \%$ and $42 \%$ transmittance correspond to primary alcohol and alkyne, respectively.

The prevalent peaks of the GL could be seen in Fig. 2 . The spectrum exhibits eleven distinct peaks from 3770.96 to $397.35 \mathrm{~cm}^{-1}$. The absorption band located at 3770.96 and $3421.83 \mathrm{~cm}^{-1}$ with $25 \%$ and $12 \%$ transmittance, respectively are characteristics of $\mathrm{O}-\mathrm{H}$ stretching vibration. These peaks were observed to have shifted at 2939.61 and $2396.63 \mathrm{~cm}^{-1}$ with $20 \%$ and $30 \%$ transmittance. The peak located at $2281.87 \mathrm{~cm}^{-1}$ with $31 \%$ transmittance is a characteristic of phosphine $\mathrm{P}-\mathrm{H}$ stretching of a phosphorous compound. The peak found at $1641.48 \mathrm{~cm}^{-1}$ with $20 \%$ transmittance is a characteristic of amide that exhibits $\mathrm{C}=\mathrm{O}$ stretching (Fig. 2). The peaks at 1424.48, 1241.23, and 1048.35 $\mathrm{cm}^{-1}$ with $25 \%, 27 \%$, and $22 \%$ transmittance, respectively represent $\mathrm{C}-\mathrm{O}$ axial deformation. The peaks located at $679.93 \mathrm{~cm}^{-1}$ with $27 \%$ transmittance is a characteristic of nitrate $\mathrm{NO}_{2}$ bending.

\subsection{Microbial count}

The total viable count (TVC), coliform, and mold counts were used to ascertain the available microbial population in the GL and COCS (Table 2). Balba et al. [23] emphasized that the soil analysis of the total heterotrophic microbial count would indicate the degree at which the soil could support contaminant degradation.

Results from Table 2 indicated that the GL could positively affect the soil microbial community. This was as it contained viable sources of microbial populations of 2.6 $\times 10^{7} \mathrm{CFUg}^{-1}, 7.8 \times 10^{3} \mathrm{CFUg}^{-1}$, and $6.9 \times 10^{3} \mathrm{CFUg}^{-1}$ for TVC, coliform, and mold counts, respectively. Consequently, the microbial count in the control (Table 2) showed scarce microbial populations of $1.1 \times$ $10^{3} \mathrm{CFUg}^{-1}, 2.1 \times 10^{3} \mathrm{CFUg}^{-1}$, and $6.3 \times 10^{3} \mathrm{CFUg}^{-1}$ for TVC, coliform, and mold counts, respectively.

\subsection{Factor sensitivity analysis}

3.3.1 Effect of initial CO concentration on CO degradation

$\mathrm{CO}$ concentration influenced the microbial degradation of $\mathrm{CO}$ as observed in both COCS-GL and the control. The effect of the initial $\mathrm{CO}$ concentration on $\mathrm{CO}$ degradation in the contaminated soil was investigated at different $\mathrm{CO}$ concentrations $\left(50,70\right.$, and $\left.90 \mathrm{gL}^{-1}\right)$. The
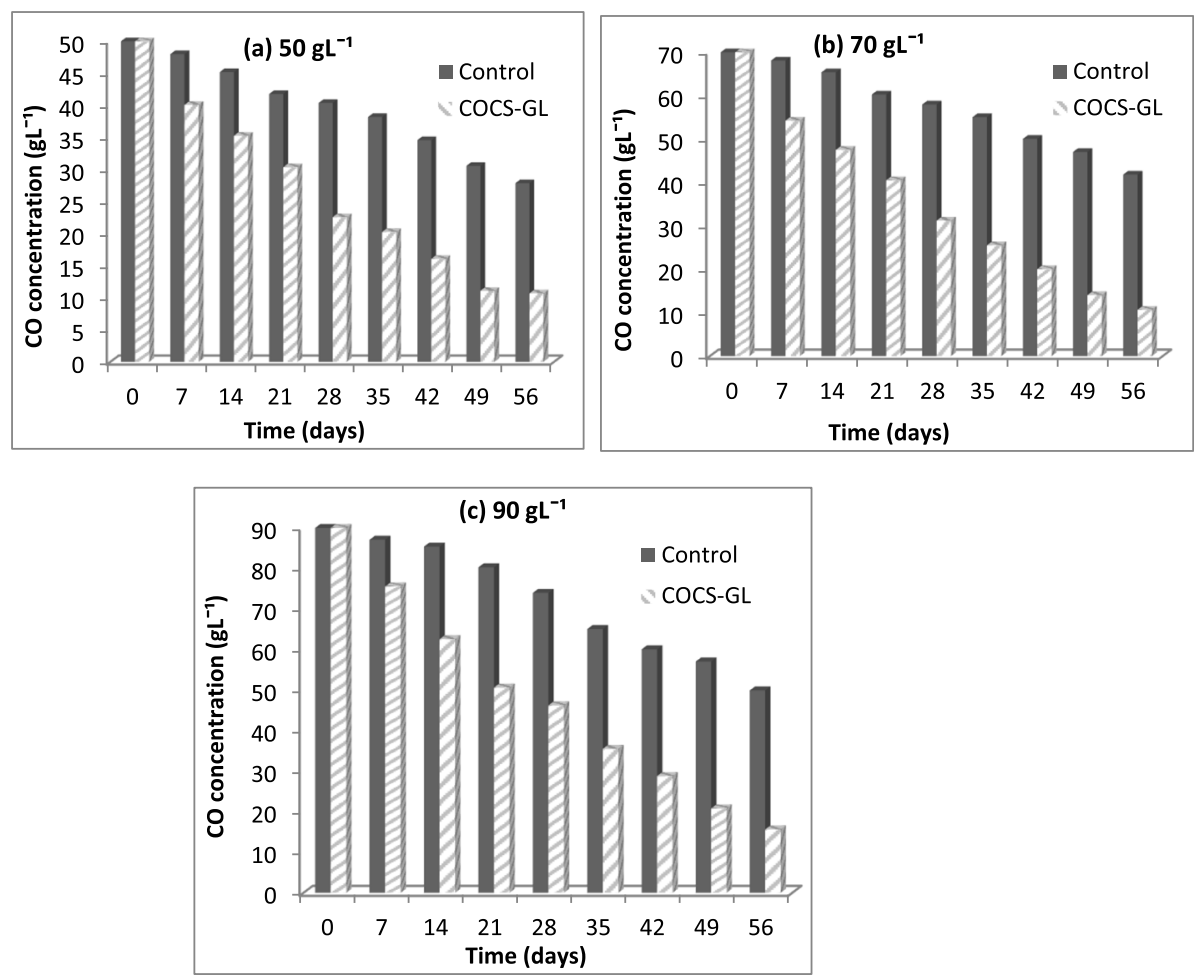

Fig. 3 a-c Effect of initial CO concentration on CO degradation (bars represents \pm SD of triplicates measurements) 


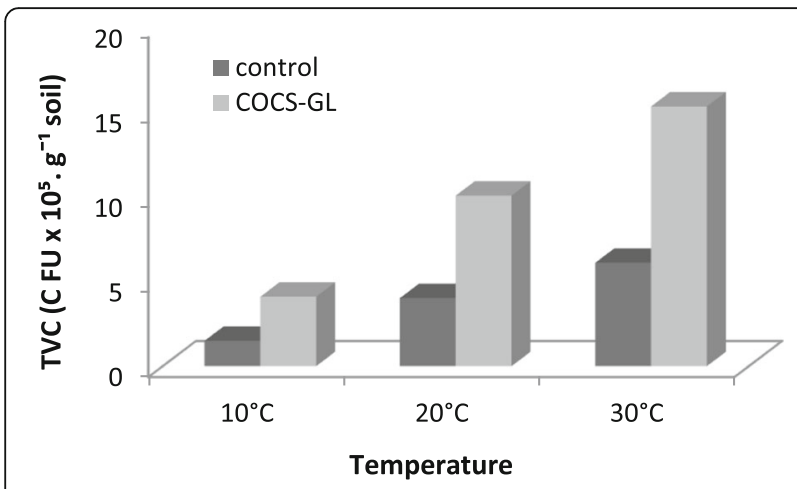

Fig. 4 Effect of temperature on soil TVC, (bars represents \pm SD of triplicates measurement)

temperature and quantity of GL used were fixed at $30{ }^{\circ} \mathrm{C}$ and $100 \mathrm{~g}$, respectively.

Figure $3 \mathrm{a}-\mathrm{c}$ showed the levels of $\mathrm{CO}$ reductions in the $\mathrm{CO}$ concentrations during the remediation period. After 56 days of treatment, the $\mathrm{CO}$ concentrations of 50,70 , and $90 \mathrm{gL}^{-1}$ for COCS-GL reduced to 26.1, 21.2, and $15.6 \mathrm{gL}^{-1}$, respectively. These reductions resulted in $\mathrm{CO}$ degradation rates of $49.4 \%, 69.6 \%$, and $89.8 \%$, respectively. However, in the control, the initial CO concentrations reduced to $44.4,59.1$, and $70.8 \mathrm{gL}^{-1}$ for 50,70 , and $90 \mathrm{gL}^{-1}$, which corresponded to $11.2 \%, 15.5 \%$, and $21.3 \%$ degradation rates, respectively (Fig. $3 \mathrm{a}-\mathrm{c}$ ).

\subsubsection{Effects of temperature on $\mathrm{CO}$ degradation}

It is well established that temperature is a critical environmental factor affecting microbial degradation [24]. Batch experiments were performed with COCS-GL and the control at three different temperatures $\left(10^{\circ} \mathrm{C}, 20^{\circ} \mathrm{C}\right.$, and $30^{\circ} \mathrm{C}$ ) to determine the effect of this factor on the microbial degradation of $\mathrm{CO}$. The water bath shaking speed was maintained at $150 \mathrm{rpm}$ for $30 \mathrm{~min}$ contact time and constant CO concentration. The TVC of soil microbial population at the incubation temperatures

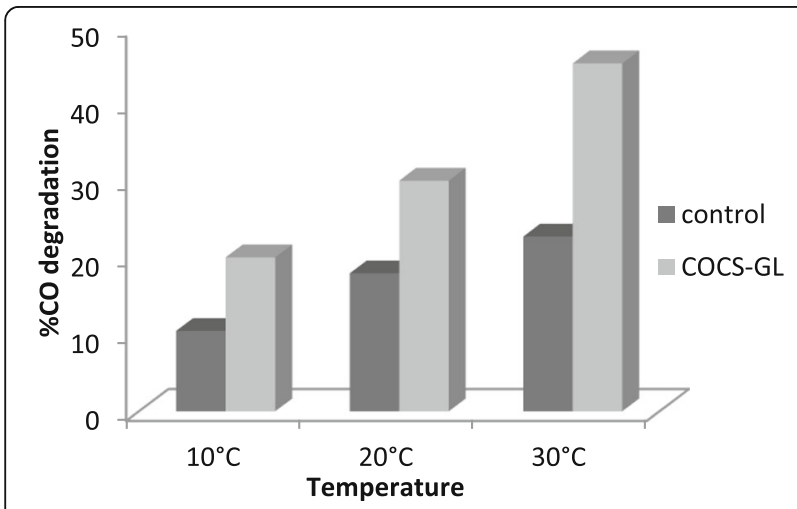

Fig. 5 Effect of temperature on CO degradation, (bars represents \pm SD of triplicates measurement)
Table 3 ANOVA of temperature effect on CO degradation

\begin{tabular}{llllll}
\hline & Sum of squares & df & Mean square & $F$ & $P$ value \\
\hline Between groups & 1075 & 2 & 537.5 & 64.5 & 0.003 \\
Within groups & 25 & 3 & 8.333 & & \\
Total & 1100 & 5 & & & \\
\hline
\end{tabular}

were observed to determine the optimum temperature with higher TVCs. In Fig. 4, the TVCs of $15.8 \times 10^{6}$ $\mathrm{CFUg}^{-1}$ and $6 \times 10^{6} \mathrm{CFUg}^{-1}$ were observed for COCS$\mathrm{GL}$ and control, respectively at $30^{\circ} \mathrm{C}$. The $\mathrm{CO}$ degradation rates of $(52.1 \%)$ and $25 \%$ were recorded at $30{ }^{\circ} \mathrm{C}$ for COCS-GL and control, respectively (Fig. 5).

\subsection{Statistical analysis \\ 3.4.1 One-way ANOVA of temperature effect on CO degradation}

The result from the one-way ANOVA for temperature effect on $\mathrm{CO}$ degradation was presented in Table 3. The one-way ANOVA was used to judge the statistically significant difference between and within the group means. The one-way ANOVA results in Table 3 indicate a statistical significance difference between and within the group means $(P<0.05)$, thus excluding the null hypothesis. The result further indicated that the mean range of temperatures $\left(10{ }^{\circ} \mathrm{C}, 20^{\circ} \mathrm{C}\right.$, and $30{ }^{\circ} \mathrm{C}$ ) on $\mathrm{CO}$ degradation was statistically significant at $P<0.05$.

The statistical significance $(P<0.05)$ of all pairs in the group was further examined using the Turkey's post-hoc analysis as shown in Table 4 . From the Turkey's posthoc analysis, asterisks $(*)$ were used to denote the pairs that were statistically significant at $P<0.05$. The Turkey's post-hoc analysis in Table 4 revealed that the mean difference (I-J) within the temperature (I) of $30^{\circ} \mathrm{C}$ were all significant $(P<0.05)$. Consequently, the pairs within $10{ }^{\circ} \mathrm{C}$ and $20^{\circ} \mathrm{C}$ were not all significant $(P>0.05)$. The statistical significance of the mean temperature

Table 4 Turkey's post-hoc analysis of temperature effect on CO degradation

\begin{tabular}{|c|c|c|c|c|c|c|}
\hline \multirow[t]{2}{*}{$\begin{array}{l}\text { (I) } \\
\text { Temperature }\end{array}$} & \multirow[t]{2}{*}{$\begin{array}{l}(\mathrm{J}) \\
\text { Temperature }\end{array}$} & \multirow[t]{2}{*}{$\begin{array}{l}\text { Mean } \\
\text { difference } \\
(I-J)\end{array}$} & \multirow[t]{2}{*}{$\begin{array}{l}\text { Std. } \\
\text { error }\end{array}$} & \multirow[t]{2}{*}{$P$ values } & \multicolumn{2}{|c|}{$\begin{array}{l}95 \% \\
\text { Confidence } \\
\text { interval }\end{array}$} \\
\hline & & & & & $\begin{array}{l}\text { Lower } \\
\text { bound }\end{array}$ & $\begin{array}{l}\text { Upper } \\
\text { bound }\end{array}$ \\
\hline \multirow[t]{2}{*}{$10^{\circ} \mathrm{C}$} & $20^{\circ} \mathrm{C}$ & -12.500 & 2.887 & 0.846 & -24.56 & 20.44 \\
\hline & $30^{\circ} \mathrm{C}$ & $-32.500^{*}$ & 2.887 & 0.003 & -44.56 & -20.44 \\
\hline \multirow[t]{2}{*}{$20^{\circ} \mathrm{C}$} & $10^{\circ} \mathrm{C}$ & $12.500^{*}$ & 2.887 & 0.046 & 10.44 & 24.56 \\
\hline & $30^{\circ} \mathrm{C}$ & -20.000 & 2.887 & 0.613 & -32.06 & -7.94 \\
\hline \multirow[t]{2}{*}{$30^{\circ} \mathrm{C}$} & $10^{\circ} \mathrm{C}$ & $32.500^{*}$ & 2.887 & 0.003 & 20.44 & 44.56 \\
\hline & $20^{\circ} \mathrm{C}$ & $20.000^{*}$ & 2.887 & 0.013 & 7.94 & 32.06 \\
\hline
\end{tabular}

*The mean difference is significant at $P$ values less than 0.05 
Table 5 ANOVA for the effect of initial CO concentration on CO degradation

\begin{tabular}{llllll}
\hline & Sum of squares & df & Mean square & $F$ & $P$ value \\
\hline Between groups & 1600 & 2 & 800 & 64 & 0.003 \\
Within groups & 37.5 & 3 & 12.5 & & \\
Total & 1637.5 & 5 & & & \\
\hline
\end{tabular}

difference at $30{ }^{\circ} \mathrm{C}$ suggests that the microbial degradation of $\mathrm{CO}$ was enhanced at $30^{\circ} \mathrm{C}$.

\subsubsection{One-way ANOVA for the effect of initial CO concentration on $\mathrm{CO}$ degradation}

Table 5 shows the one-way ANOVA result for the effect of initial CO concentration on CO degradation. Accordingly, the rejection of the null hypothesis was as a result of the statistical significance difference $(P<0.05)$ that exists between and within the group means. The differences between the $\mathrm{CO}$ concentration means were due to the variation in the initial $\mathrm{CO}$ concentrations.

Further studies of the statistical group means were investigated using the Turkey's post-hoc analysis (Table 6). These investigations aimed to identify the specific group pairs that were indeed statistically significant $(P<0.05)$. From the Turkey's post-hoc analysis in Table 6 , asterisks $\left(^{*}\right)$ were used to identify statistically significant pairs with $P<0.05$. The Turkey's post-hoc results indicated that the mean difference (I-J) within the $\mathrm{CO}$ concentrations (I) of 70 and $90 \mathrm{gL}^{-1}$ were all statistically significant $(P<0.05)$. However, the Turkey's post-hoc multiple comparisons within the $50 \mathrm{gL}^{-1}$ initial $\mathrm{CO}$ concentration were not all statistically significant $(P>0.05)$. The above result revealed a significant $\mathrm{CO}$ degradation at 70 and 90 $\mathrm{gL}^{-1}$ initial CO concentrations.

\subsection{Process kinetics}

\subsubsection{First- and second-order $\mathrm{CO}$ degradation kinetics}

In order to evaluate the $\mathrm{CO}$ degradation kinetic parameters for COCS-GL and the control, experimental data were fitted to the nonlinear and linear forms of first- and second-order kinetics models (Table 7). From Table 7, the initial and final CO concentration in the COCS at time $t$ is represented by [Co] and [Ct], respectively. $K_{1}$ and $K_{2}$ are the first- and second-order $\mathrm{CO}$ degradation rate constants $\left(\right.$ day $\left.^{-1}\right)$, respectively while $t$ is the time in days [26]. The first order plot of $\ln [\mathrm{Ct}]$ versus $t$ yields a straight line with $K_{1}$ and $\ln [\mathrm{Co}]$ as the slope and intercept, respectively [27]. On the other hand, the second-order plot of $\frac{1}{[\mathrm{Ct}]}$ versus $t$ yields a straight line with $K_{2}$ and $\frac{1}{[\mathrm{Co}]}$ as the slope and intercept, respectively (Table 7).

The nonlinear CO degradation rate constants corresponding to each initial $\mathrm{CO}$ concentration were obtained using the linear parameters as the initial guess [25]. The variation in experimental and theoretically obtained data as a function of initial CO concentration and time for the nonlinear regression is presented in Figs. $6 a-c, 7 a-c, 8 a-c$, and $9 a-c$. The kinetic parameters at different initial $\mathrm{CO}$ concentrations for first- and second-order kinetic models are presented in Tables 8 and 9 .

From Tables 8 and 9, the first- and second-order rate constants obtained for $\mathrm{CO}$ degradation were higher in the COCS-GL. Within the range of CO concentrations (50 to $90 \mathrm{gL}^{-1}$ ) used in this study, the $\mathrm{CO}$ degradation rate constants for the first- and second-order kinetic models $\left(K_{1}\right.$ and $K_{2}$ ) were observed to be highest at $90 \mathrm{gL}^{-1}$ while lower rate constants were obtained at $50 \mathrm{gL}^{-1}$ (Tables 8 and 9). The biological half-lives, which were the time taken by the indigenous microbial population to degrade half of the initial $\mathrm{CO}$ concentrations, were also calculated using Eqs. (2) and (3). The first order biological half-life is dependent on the first-order $\mathrm{CO}$ degradation rate constant $\left(K_{1}\right)$ according to Eq. (2). In contrast, the secondorder biological half-life is dependent on the second-order $\mathrm{CO}$ degradation rate constant $\left(K_{2}\right)$ and the initial $\mathrm{CO}$ concentration as expressed in Eq. (3):

$$
\mathrm{T}_{1}^{1 / 2}=\frac{\ln 2}{\mathrm{~K}_{1}}
$$

Table 6 Turkey's post-hoc analysis for the effect of initial CO concentration on CO degradation

\begin{tabular}{|c|c|c|c|c|c|c|}
\hline \multirow{2}{*}{$\begin{array}{l}\text { (I) } \\
\text { Concentration }\end{array}$} & \multirow{2}{*}{$\begin{array}{l}(J) \\
\text { Concentration }\end{array}$} & \multirow{2}{*}{$\begin{array}{l}\text { Mean } \\
\text { difference } \\
(I-J)\end{array}$} & \multirow{2}{*}{$\begin{array}{l}\text { Std. } \\
\text { error }\end{array}$} & \multirow{2}{*}{$\begin{array}{l}P \\
\text { values }\end{array}$} & \multicolumn{2}{|c|}{ 95\% Confidence interval } \\
\hline & & & & & Lower bound & Upper bound \\
\hline \multirow[t]{2}{*}{$50 \mathrm{gL}^{-1}$} & $70 \mathrm{gL}^{-1}$ & $-20.000^{*}$ & 3.536 & 0.022 & -34.77 & -5.23 \\
\hline & $90 \mathrm{gL}^{-1}$ & -40.000 & 3.536 & 0.663 & -54.77 & -25.23 \\
\hline \multirow[t]{2}{*}{$70 \mathrm{gL}^{-1}$} & $50 \mathrm{gL}^{-1}$ & $20.000^{*}$ & 3.536 & 0.022 & 5.23 & 34.77 \\
\hline & $90 \mathrm{gL}^{-1}$ & $-20.000^{*}$ & 3.536 & 0.002 & -34.77 & -5.23 \\
\hline \multirow[t]{2}{*}{$90 \mathrm{gL}^{-1}$} & $50 \mathrm{gL}^{-1}$ & $40.000^{*}$ & 3.536 & 0.003 & 25.23 & 54.77 \\
\hline & $70 \mathrm{gL}^{-1}$ & $20.000^{*}$ & 3.536 & 0.022 & 5.23 & 34.77 \\
\hline
\end{tabular}

*The mean difference is significant at $P$ values less than 0.05 
Table 7 CO degradation kinetics models

\begin{tabular}{|c|c|c|}
\hline Models & Plots & Refs \\
\hline $\begin{array}{l}\text { Nonlinear first-order } \\
{[\mathrm{Ct}]=[\mathrm{Co}] \mathrm{e}^{-\mathrm{K}_{1} t}}\end{array}$ & {$[\mathrm{Ct}]$ vs $t$} & [25] \\
\hline $\begin{array}{l}\text { Linear first order } \\
\ln [\mathrm{Ct}]=-\mathrm{K}_{1} \mathrm{t}+\operatorname{In}[\mathrm{Co}]\end{array}$ & $\ln [\mathrm{Ct}]$ vs $t$ & [26] \\
\hline $\begin{array}{l}\text { Nonlinear second-order } \\
{[\mathrm{Ct}]=\frac{1}{k_{2} \cdot t+\frac{1}{[\text { co }]}}}\end{array}$ & {$[\mathrm{Ct}]$ vs $t$} & [25] \\
\hline $\begin{array}{l}\text { Linear second-order } \\
\frac{1}{[\mathrm{Ct}]}=K_{2} t+\frac{1}{[\mathrm{Co}]}\end{array}$ & $\frac{1}{[C t]}$ vs $t$ & [27] \\
\hline
\end{tabular}

$$
\mathrm{T}_{1}^{1 / 2}=\frac{1}{\mathrm{~K}_{2}[\mathrm{Co}]}
$$

The results obtained from the biological half-lives indicated that the microbial population took more time to degrade the $\mathrm{CO}$ at $50 \mathrm{gL}^{-1}$ initial $\mathrm{CO}$ concentration. For example, in COCS-GL and for first-order kinetic model, the microbial population took 22 days to degrade half of the initial $\mathrm{CO}$ concentration of $50 \mathrm{gL}^{-1}$; whereas, it took 17 and 11 days, degrade half of the 70 and $90 \mathrm{gL}^{-1}$ initial $\mathrm{CO}$ concentrations, respectively.

\subsection{Error analysis of the kinetic models}

The predictive capabilities of both first- and secondorder kinetic models for $\mathrm{CO}$ degradation using the error functions in Table 1 were compared. The statistical error analysis employing the error functions such as RMSE, ARED, MAE, SEP, and $R^{2}$ for both the first- and second-order kinetic models have been calculated and presented in Table 10.

The results showed that the data obtained for the second-order kinetic model were higher than the firstorder kinetic model (Table 10). These observations revealed that lower values of the RMSE, ARED, MAE, and SEP were obtained for the first-order kinetic model. The results further indicated that the first-order kinetic model gave a better fit to the experimental data on $\mathrm{CO}$ degradation. Furthermore, linear regression analysis between the $\mathrm{CO}$ degradation data predicted by the first- and secondorder kinetic models with their corresponding experimental values was investigated (Fig. 10a and b). The $R^{2}$ values were used to judge how close the data are to the fitted regression line. In Fig. 10a and b, the first-order model predictions lie much closer to the fitted regression line in comparison with the second-order kinetic model. The $R^{2}$ values for the first-order kinetic model were 0.977 and 0.971 for COCS-GL and control, respectively. On the other hand, the $R^{2}$ values for the second-order kinetic model were 0.923 and 0.887 for COCS-GL and control, respectively. These results revealed that the first-order kinetic model performed better. However, the $R^{2}$ values for COCS-GL were higher than the control for both the first- and second-order kinetic models.

\section{Discussion}

4.1 Characterizations of the COCS and GL

The prevalent functional group of the COCS was investigated using the FTIR technique as presented in
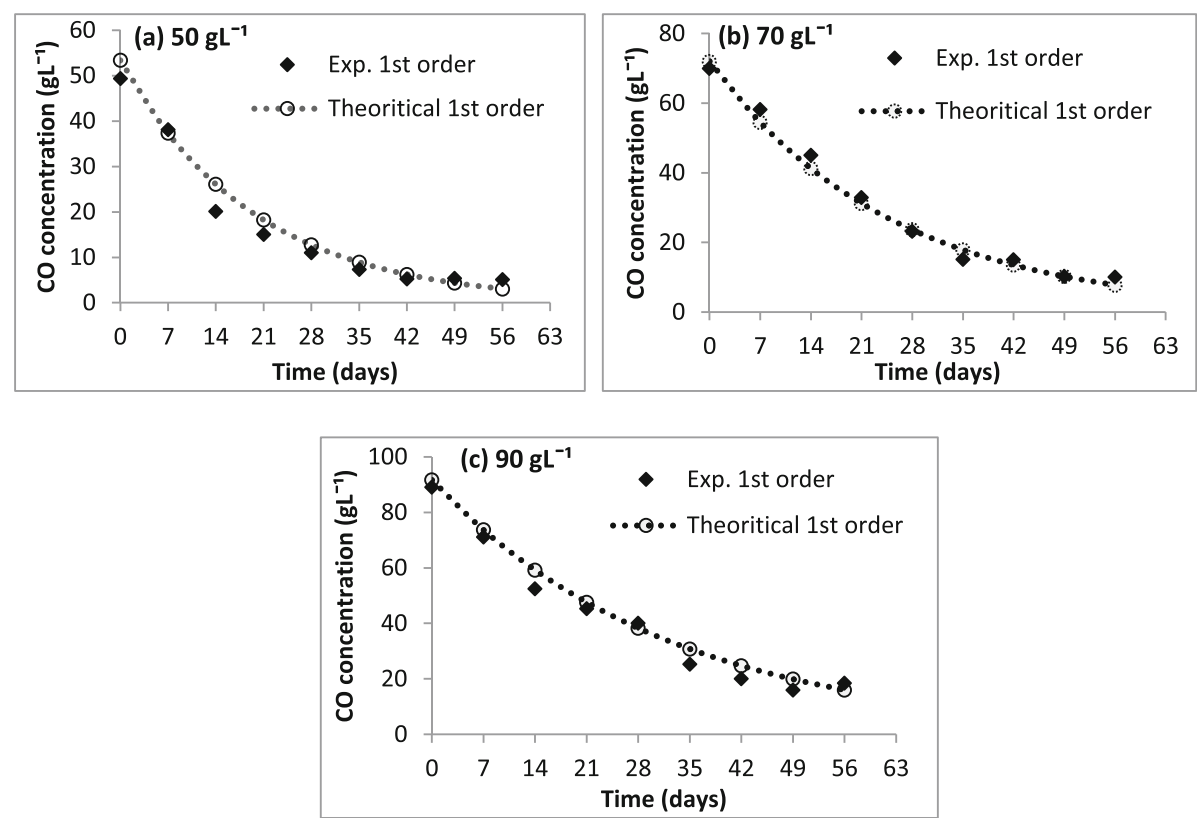

Fig. 6 a-c First-order plots of CO degradation for COCS-GL 

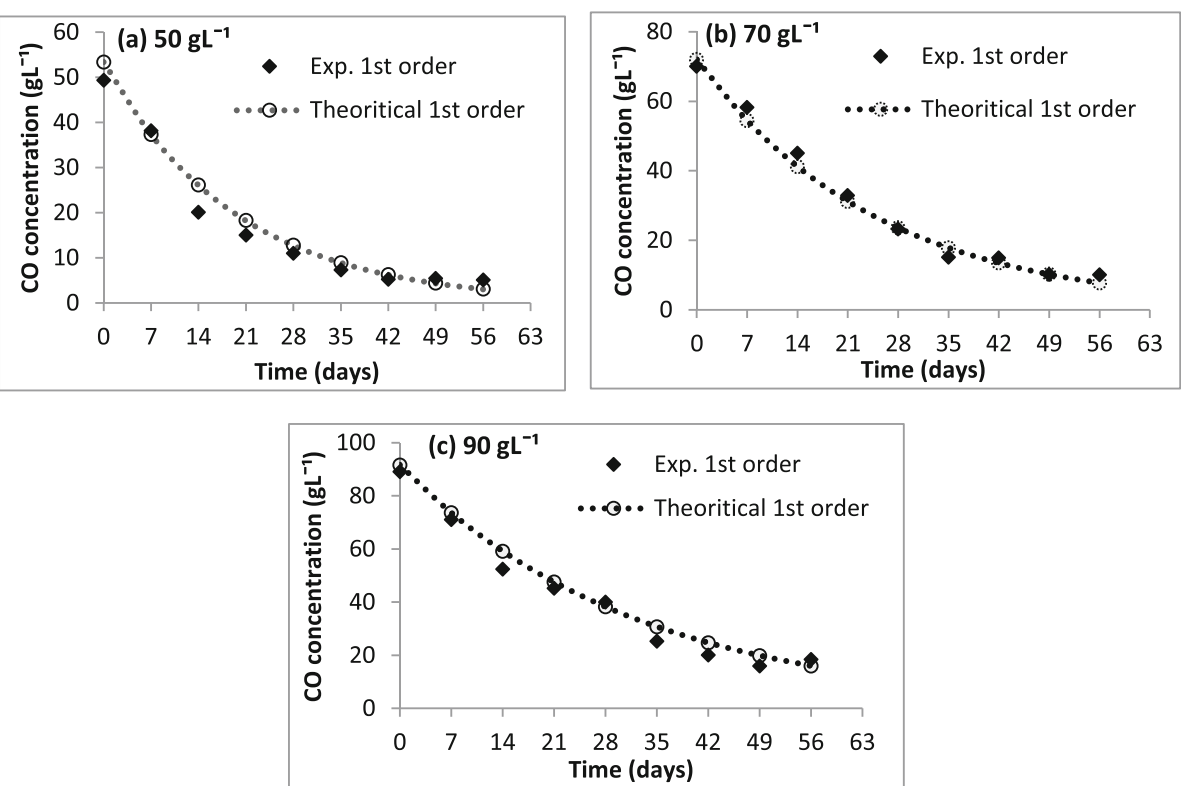

Fig. 7 a-c First-order plots of CO degradation for the control

Fig. 1. Forrester et al. [28] attributed the peak located at $3471.98 \mathrm{~cm}^{-1}$ to the first overtone vibration of $\mathrm{CH}_{2}$ symmetric deformation in total petroleum hydrocarbon (TPH). This band was not observed in the spectrum pattern of GL and could be attributed to the amount of spiked CO in the COCS [28]. Also, in the spectrum pattern of TPH, Stuart [29] attributed the peak at $1605.79 \mathrm{~cm}^{-1}$ to the aliphatic hydrocarbon compound of an alkene. However, in hydrocarboncontaminated soil, Mohd et al. [30] reported that hydroxyl and alkyne group with stretching vibrations of
$\mathrm{O}-\mathrm{H}$ and $\mathrm{C} \equiv \mathrm{C}$ were observed at $1033.88 \mathrm{~cm}^{-1}$ and $728.16 \mathrm{~cm}^{-1}$. The series of weak absorption peaks in the spectrum of COCS (Fig. 1) were related to TPH and were attributed to the vibrational frequencies of terminal methyl $\left(-\mathrm{CH}_{3}\right)$ and alkyl halides [28]. However, the FTIR peaks of the COCS indicated the presence of aliphatic and aromatic hydrocarbon compounds (Fig. 1).

The spectrum pattern of GL as indicated in Fig. 2 shows the functional groups of known organic nutrients as reported previously. These nutrients could be
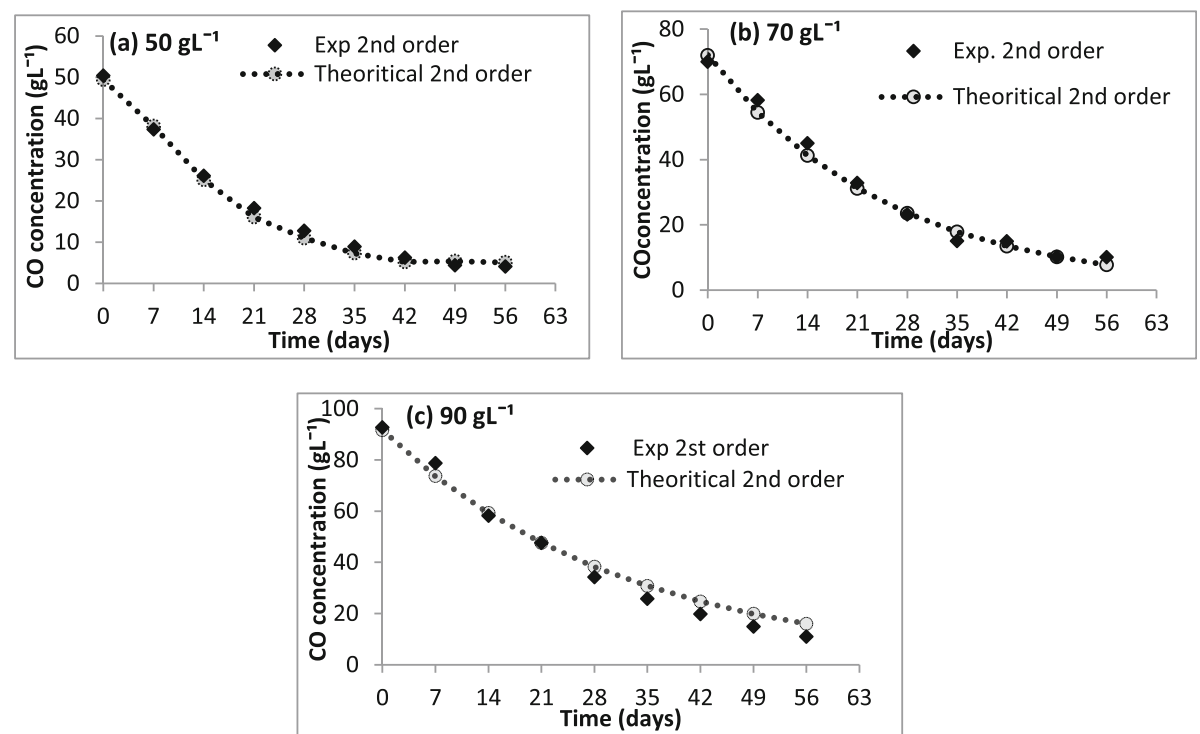

Fig. 8 a-c Second-order plots of CO degradation for COCS-GL 

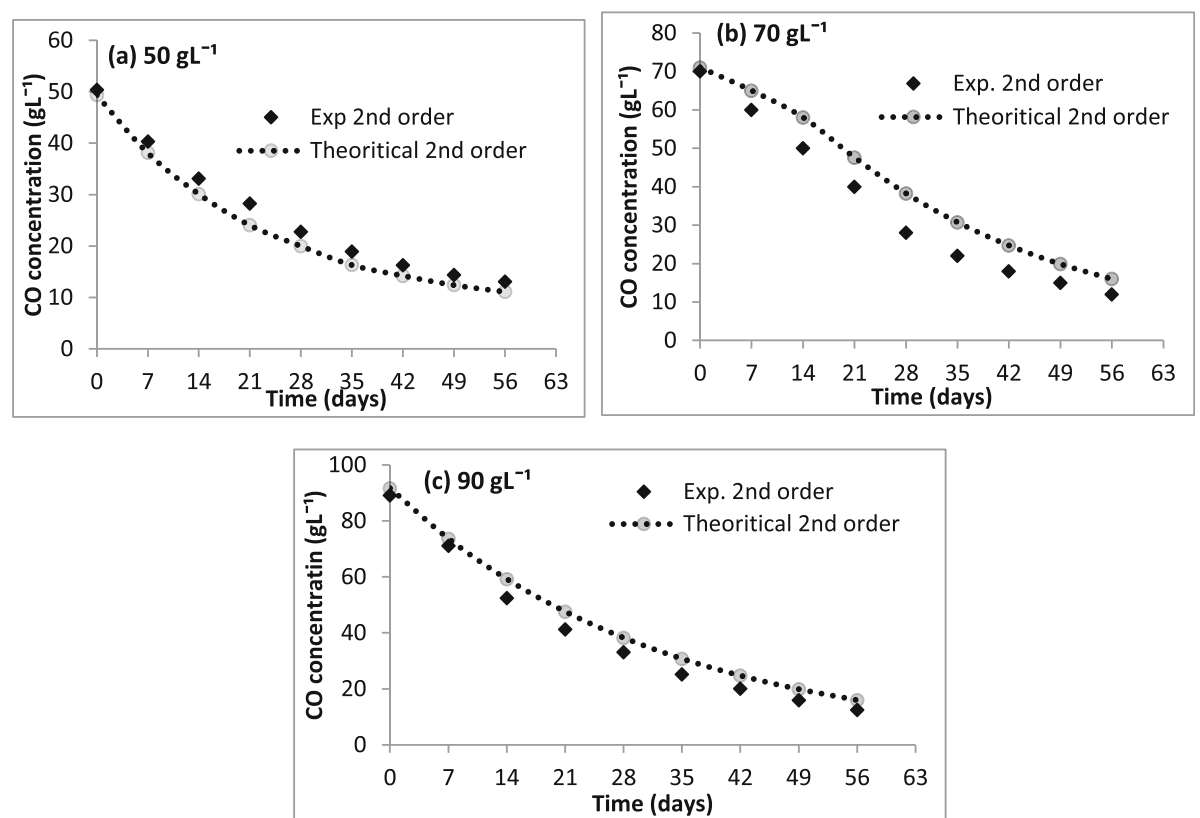

Fig. 9 a-c Secondorder plots of CO degradation for the control

contributing to the $\mathrm{CO}$ degradation process. Pavia et al. [31] reported that $\mathrm{N}-\mathrm{H}$ stretching of amine could also be assigned at the absorption bands at 3770.96 and $3421.83 \mathrm{~cm}^{-1}$. Also, the peaks at 2939.61 and $2396.63 \mathrm{~cm}^{-1}$ were indicative of the presence of phosphorous and ester $\mathrm{P}-\mathrm{H}$ stretching [29]. However, Stuart [29] and Pavia et al. [31] noted that the bands at 2939.61 and $2396.63 \mathrm{~cm}^{-1}$ represent $\mathrm{N}-\mathrm{CH}_{2}$ stretching vibration of tertiary amine (Fig. 2). Likewise, Stuart [29] attributed the band at $1641.48 \mathrm{~cm}^{-1}$ to the vibration of the $\mathrm{N}-\mathrm{H}$ primary amine group, which was indicative of nitrogen may be due to the carbonyl stretching vibration. Stevenson [32] and Stuart [29] assigned the absorption band at 1424.48 $\mathrm{cm}^{-1}, 1241.23 \mathrm{~cm}^{-1}$ to the $\mathrm{C}-\mathrm{O}$ axial deformation of polysaccharides. From the observed FTIR peaks, it was indicative that phosphorous and nitrogen compounds were present in GL (Fig. 2).

\subsection{Microbial count}

Observations made from the microbial count results showed that the addition of GL in COCS could affect the general nutrient cycling and microbial biomass of the contaminated soil. This was as the microbial count (TVC, coliform, and mold) in GL was high (Table 2). Previously, Czurak-Dainard [33] and Alkatib et al. [34] reported that soils with histories of pig and goat manure application generally contained higher concentrations of microbial biomass carbon compared with soil with no manure. The low microbial counts in the control could be attributed to the microbial competition for the scarce nutrient in the COCS $[35,36]$. However, the low microbial population and organic matter content of CO-contaminated soils have been reported previously [37].

\subsection{Effect of initial CO concentration}

The $\mathrm{CO}$ degradation rate was observed to have increased at $90 \mathrm{gL}^{-1}$ in both the COCS-GL and control. Accordingly, $89.8 \%$ and $21.3 \% \mathrm{CO}$ degradation rates were obtained at $90 \mathrm{gL}^{-1}$ for COCS-GL and control, respectively. The bioavailability of the $\mathrm{CO}$ at $90 \mathrm{gL}^{-1}$ might be sustaining the required microbial action on $\mathrm{CO}$. The high rate of $\mathrm{CO}$ degradation in the COCS-

Table 8 First-order CO degradation kinetic parameters

\begin{tabular}{|c|c|c|c|c|c|c|c|}
\hline \multicolumn{4}{|l|}{ COCS-GL } & \multicolumn{4}{|l|}{ Control } \\
\hline Initial CO conc. $\left(\mathrm{gL}^{-1}\right)$ & $K_{1}\left(\right.$ day $\left.^{-1}\right)$ & $T / 2$ (days) & $R^{2}$ & Initial CO conc. $\left(\mathrm{gL}^{-1}\right)$ & $K_{1}\left(\operatorname{day}^{-1}\right)$ & $T / 2$ (days) & $R^{2}$ \\
\hline 50 & 0.045 & 22 & 0.903 & 50 & 0.022 & 32 & 0.822 \\
\hline 70 & 0.051 & 17 & 0.918 & 70 & 0.026 & 25 & 0.945 \\
\hline 90 & 0.069 & 11 & 0.965 & 90 & 0.034 & 15 & 0.769 \\
\hline
\end{tabular}

$K_{1}$ is the first-order rate constant $\left(\right.$ day $\left.^{-1}\right), T / 2$ is the first-order biological half-life (days) 
Table 9 Second order CO degradation kinetic parameters

\begin{tabular}{|c|c|c|c|c|c|c|c|}
\hline \multicolumn{4}{|l|}{ COCS-GL } & \multicolumn{4}{|l|}{ Control } \\
\hline Initial CO conc. $\left(\mathrm{gL}^{-1}\right)$ & $K_{2}\left(\right.$ day $\left.^{-1}\right)$ & $T_{2}^{1 / 2}\left(\mathrm{gL}^{-1} \mathrm{day}^{-1}\right)$ & $R^{2}$ & Initial CO conc. $\left(\mathrm{gL}^{-1}\right)$ & $K_{2}\left(\right.$ day $\left.^{-1}\right)$ & $T_{2}^{1 / 2}\left(\mathrm{gL}^{-1} \mathrm{day}^{-1}\right)$ & $R^{2}$ \\
\hline 50 & 0.012 & 22 & 0.981 & 50 & 0.012 & 35 & 0.912 \\
\hline 70 & 0.015 & 20 & 0.896 & 70 & 0.014 & 28 & 0.813 \\
\hline 90 & 0.028 & 15 & 0.971 & 90 & 0.024 & 21 & 0.766 \\
\hline
\end{tabular}

$K_{2}$ is the second-order rate constant $\left(\right.$ day $\left.^{-1}\right), T_{2} \frac{1}{2}$ is second-order biological half-life $\left(\mathrm{gL}^{-1} \mathrm{day}^{-1}\right)$

GL indicated that the COCS treated with GL enhanced $\mathrm{CO}$ degradation. Similar results on the use of organic nutrients to enhance the bioremediation of contaminated environments have been previously reported [12, 13, 17]. Furthermore, the FTIR result for GL revealed that nitrogen and phosphorous were the dominant organic nutrients in GL [2]. These nutrients may have contributed to the $\mathrm{CO}$ degradation due to the increase in the microbial count (TVC, coliform, and mold). Also, previous studies reported that these nutrients were responsible for enhanced contaminant degradation by increasing the growth rate of the available microbial population [38].

\subsection{Effects of temperature}

The majority of the soil microorganisms were mesophilic with maximum growth temperature between $25^{\circ} \mathrm{C}$ and $45^{\circ} \mathrm{C}[24,39,40]$. This was in accordance with the TVC $\left(15.8 \times 10^{5} \mathrm{CFUg}^{-1}\right)$ observed in COCS-GL at $30^{\circ} \mathrm{C}$, where it was obvious that the added organic material (GL) favored the TVC in COCS (Fig. 4). However, in the relationship between soil microbial population and count, Critter et al. [41] demonstrated that different organic amendments significantly affected the microbial quantity and count. The $\mathrm{CO}$ degradation examined at the respective temperatures $\left(10{ }^{\circ} \mathrm{C}, 20^{\circ} \mathrm{C}\right.$, and $\left.30^{\circ} \mathrm{C}\right)$ showed that the maximum $\mathrm{CO}$ degradation (52.1\%) was obtained at $30{ }^{\circ} \mathrm{C}$ (Fig. 5). This could be attributed to the maximum TVC recorded at $30^{\circ} \mathrm{C}$. Similarly, Muftah et al. [42] reported that at a temperature of about $30{ }^{\circ} \mathrm{C}$, the activity of $P$. putida and its ability to degrade phenol was optimized.

Table 10 Error comparisons between first- and second-order

\begin{tabular}{lll}
\hline Error & \multicolumn{2}{l}{ CO degradation } \\
\cline { 2 - 3 } functions & First-order & Second-order \\
\hline RMSE & 0.1798 & 1.6692 \\
ARED & 0.3613 & 0.9894 \\
MAE (\%) & 1.0198 & 2.0193 \\
SEP (\%) & 1.2176 & 6.2213 \\
$R^{2}$ & 0.9761 & 0.9017 \\
\hline
\end{tabular}

\subsection{Process kinetics for $\mathrm{CO}$ degradation}

The biological half-live for the first-order kinetic model indicated that $90 \mathrm{gL}^{-1}$ (11 days) degrades faster than $50 \mathrm{gL}^{-1}$ (22 days) (Tables 8 and 9). This observation revealed that the $90 \mathrm{gL}^{-1}$ of $\mathrm{CO}$ could be satisfying the microbial demands for carbon while $50 \mathrm{gL}^{-1}$ might not be enough for microbial action on CO. However, these observations were in conformance with the works of Zappi et al. [43] where the degradation of poly-aromatic hydrocarbon did not occur at low concentration even an additional carbon source was added. The $\mathrm{CO}$ degradation rate constant for the first-order kinetic model $\left(K_{1}\right)$ showed a faster $\mathrm{CO}$ degradation at $90 \mathrm{gL}^{-1}\left(0.069 \mathrm{day}^{-1}\right)$ in comparison with the rate constant obtained at $50 \mathrm{gL}^{-1}(0.045$ $\mathrm{day}^{-1}$ ) for both the COCS-GL and control. A similar observation was made in the second-order kinetics model (Tables 8 and 9). The values of the rate constants and half-lives obtained in this study were lower than those obtained previously in the bioremediation of total petroleum hydrocarbon (TPH) $[11,44]$. This could be due to different experimental processes, analysis, and organic material used in the remediation process. Coupled with the addition of GL in the COCS, the aeration and mixing process of the COCS treatment might also be enhancing $\mathrm{CO}$ degradation [45]. The aeration and mixing processes gave rise to the increased microbial activity and aerobic nature of CO degradation [45]. Also, Nilanjana and Preethy [46] emphasized that the most rapid and complete degradation of the majority of organic pollutants is brought about under aerobic conditions. The $\mathrm{CO}$ degradation in the control could be attributed to the stimulation of the indigenous microbial population through the aeration and mixing processes as GL was not added. Similarly, Mohsen et al. [45] reported that the degradation of hydrocarbon in the control samples could be explained by the activity of the microbial population due to the aeration, and mixing processes.

\subsection{Error analysis of the kinetic models}

The lower values of the error analysis for the first-order kinetic model showed that the first-order kinetic model 

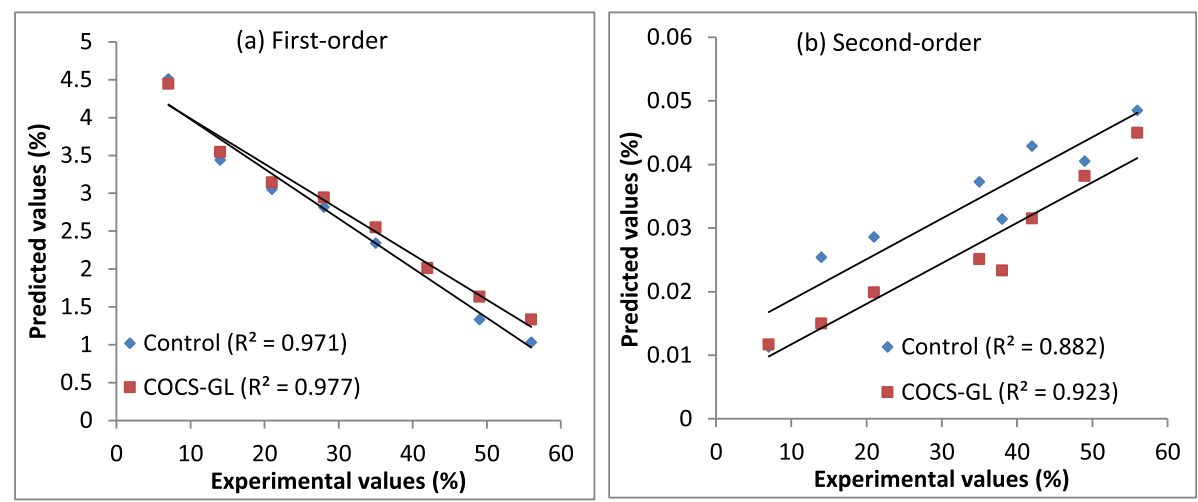

Fig. 10 a and $\mathbf{b}$ Comparison of experimental with predicted values for the first- and second-order kinetic models

performed better in the modeling of the $\mathrm{CO}$ degradation. Previous works reported that the lower the values of the error functions, the better the model goodness of fit (Kitanovic et al. 2008). Also, in the study of hydrocarbon modeling and kinetics, Anders and Haller [47] reported that the simplicity of the first-order kinetic model permits its application in degradation studies as the degradation rate is directly dependent on substrate concentration. Similarly, Jorgensen [48] emphasized that the degradation of the hydrocarbon compound is governed by the first-order kinetics model where the degradation rate of the hydrocarbon compound is proportional to its concentration.

\section{Conclusion}

The bio-stimulation of crude oil-contaminated soil using GL has been achieved. The microbial characterizations showed that GL contained active microbial populations, which were found useful during the degradation of CO. The FTIR results revealed that the inherent organic compounds in GL were phosphorous and nitrogen. The effects of process parameters such as temperature and initial CO concentration showed that the optimum conditions for the $\mathrm{CO}$ degradation process were found at $30^{\circ} \mathrm{C}$ and $90 \mathrm{gL}^{-1}$, respectively. The one-way ANOVA and Turkey's post-hoc analysis revealed that the $\mathrm{CO}$ initial concentrations of 70 and $90 \mathrm{gL}^{-1}$ were statistically significant $(P<0.05)$. Higher $\mathrm{CO}$ degradation rate constants with corresponding lower biological half-lives were obtained using the first-order kinetic model. The $\mathrm{CO}$ modeling data according to the linear regression suggested that the first-order kinetic model gave a better fit. Therefore, based on the findings of this present study, it may be concluded that GL could be used as an effective organic treatment for COCS, while the firstorder kinetic model was suitable for modeling the $\mathrm{CO}$ degradation.

\section{Abbreviations}

ANOVA: Analysis of variance; GL: Goat litter; COCS: Crude oil-contaminated soil; CO: Crude oil; COCS-GL: Crude oil-contaminated soil treated with goat litter; CFU: Colony-forming unit per gram; TVC: Total viable count;

SDA: Sabouraud dextrose agar; ARED: Average relative error deviation; RMSE: Root mean square error; SEP: Standard error of prediction; MAE: Mean absolute error; FTIR: Fourier Transform-Infrared spectrophotometer;

SD: Standard deviation; TPH: Total petroleum hydrocarbon

\section{Acknowledgements}

Not applicable.

\section{Authors' contributions}

AKA analyzed and interpreted the data, wrote the manuscript. ECC was a major contributor to the design and proofreading of the manuscript. All authors read and approved the final manuscript.

\section{Funding}

Not applicable.

\section{Availability of data and materials}

The datasets used and/or analyzed during the current study are available from the corresponding author on reasonable request.

Ethics approval and consent to participate

Not applicable.

\section{Consent for publication}

Not applicable.

\section{Competing interests}

The authors declare that they have no competing interests.

\section{Author details}

'Department of Chemical Engineering, Faculty of Engineering, Nnamdi Azikiwe University, Awka, Anambra State, Nigeria. ${ }^{2}$ Department of Agriculture and Bioresource Engineering Faculty of Engineering, Nnamdi Azikiwe University, Awka, Anambra State, Nigeria.

Received: 3 July 2019 Accepted: 13 May 2020

Published online: 22 July 2020

\section{References}

1. Adekunle MI (2011) Bioremediation of soils contaminated with Nigerian petroleum products using composted municipal waste. Bioremediation J 15(4):230-241. https://doi.org/10.1080/10889868.2011.624137

2. Ani KA, Ochin E (2018) Response surface optimization and effects of agricultural wastes on total petroleum hydrocarbon degradation Beni-suef Uni J Basic Appl Sci, 7: 564 - 574 doi.org/https://doi.org/10.1016/j.bjbas. 2018.06.009 
3. Gan S, Lau EV, Ng HK (2009) Remediation of soil contaminated with poly aromatic hydrocarbon - A Review, J Hazard Mater, 172, 532 - 549 doi.org/ https://doi.org/10.1016/j.jhazmat.2009.07.118

4. US EPA (2001) (United State Environmental Protection Agency), Remediation case study Federal Technology Round Table Report No 542-F-01-032

5. Amund OO, Nwokoye N (1993) Hydrocarbon potentials of yeast isolates from a polluted lagoon. J Sci Res Dev 1:65-68

6. Lal B, Khanna S (1996) Degradation of crude oil by Acinetobacter calcoaceticus and Alcaligenes odorans. J Appl Bacteriol 81:355-362

7. Hadibarata T, Sanro T, Kazutaka I (2009) Biodegradation of chrysene, an aromatic hydrocarbon by Polyporus sp. S133 in liquid medium, J Hazard Mater, 164: 911- 917 doi.org/https://doi.org/10.1016/j.jhazmat.2008.08.081

8. Maier R, lan LP, Charles PG (2008) Review of Basic Microbiology Concepts. Elsevier Academic Press Pp:3-7

9. Harvey C, Castro P, Harmas H, Lichtfouse E, Schaffner A (2002) Phytoremediation of poly aromatic hydrocarbon anilines and phenols. Environ Sci Pollut 9:29-47

10. Siciliano SD, Germida JJ, Bank K, Geer CW (2002) Changes in microbial community composition and function during a poly-aromatic hydrocarbon phytoremediation field trial. Appl Environ Microbiol 69:483-489

11. Agarry SE, Aermu, MO, Aworanti OA, (2013) Kinetic modeling and half-life study on enhanced bioremediation of bonny light crude oil amended with crop and animal derived organic waste, J Pet Environ Biotechnol, 112: 269 283 doi.org/https://doi.org/10.4172/2157-7463.1000137

12. Sayara T, Sarra M, Sanchez A (2010a) Effect of compost stability and contaminant concentration on bioremediation of PAH-contaminated soil through composting, J Hazard Mater 179: 999 -1006 doi.org/https://doi.org/ 10.1016/j.jhazmat.2010.03.104

13. Sayara T, Sarra M, Sanchez A (2010b) Optimization and enhancement of soil bioremediation Process by composting using experimental design techniques. Biodegradation:21, 345-356. https://doi.org/10.1007/s10532-009-9305-8

14. Awodun MA, Omonijo LI, Ojenyi SO (2007) Effect of Goat and N.P.K fertilizer on soil and leaf nutrient content growth and yield of Pepper. Int J Soil Sci 150:23-29

15. Ojeniyi SO, Adeboyega AA (2003) Effect of combine use of urea and Goat dung manure on Celosia soil sample. Nigerian Agric J 54:87-90

16. Ani KA, Chukelu C, Government RM, Ochin E (2018) Analysis and optimization processes of goat dung as a potential co-substrate in bioremediation, Alexandria Eng J, 57: 3053 - 3066 doi.org/https://doi.org/10. 1016/j.aej.2018.05.004

17. Vladimir PB, Gordana GC, Jelena M, Mila I, Srdjan M, Tatjana S, Miroslav MV (2011) Ex situ bioremediation of a soil contaminated by mazut (heavy residual fuel oil) - A field experiment. Chemosphere 83: 34 - 40 doi.org/ https://doi.org/10.1016/j.chemosphere.2011.01.020

18. Riahi K, Safa C, Bechir BT (2013) A Kinetic modeling study of phosphate adsorption onto phoenix dactylifera $L$ date palm fiber in batch mode, J King Saudi Chem Soci. 21: S143 -S152 doi.org/https:/doi.org/10.1016/j.jscs.2013.11.007

19. Garcia-Gimeno RM, Hervas-Martinez C, Rodriguez-Perez R, Cosano GZ (2005) Modeling the growth of Leuconostoc mesnteroides by artificial neural network (ANN). Int J Food Microbiol 105:317-332

20. Youssefi S, Emam-Djomeh Z, Mousavi SM (2009) Comparison of artificial neural network (ANN) and response surface methodology (RSM) in the prediction of quality parameters of spray-dried pomegranate juice. Dry Technol 27:910-917

21. Prakash MJ, Sivakumar V, Thirugnanasambandham K, Sridhar R (2013) Artificial neural network and response surface methodology in mass transfer parameter prediction during osmotic dehydration of Carica Papaya L, Alexandria Eng J 52: 507 - 516, doi. org/https:/doi.org/10.1016/j.aej.2013.06.007

22. Kitanovic HS, Milenovic D, Veeljkovic VB (2008) Empirical kinetic models for the resinoid extraction from aerial parts of Saint John's Wort (hypericum perforatum L). Biochem Eng 41:1-11

23. Balba MT, Al-Awadhi N, Al-Daher R (1998) Bioremediation of oilcontaminated soil: microbiological methods for feasibility assessment and field evaluation. J Microbiol Meth 32:155-164

24. Zekri AY, Chaalal O (2005) Effect of temperature on biodegradation of crude oil. Energy Sources 27:233-244

25. Hossani AM, Huu HN, Wenshan G (2013) Introductory of Microsoft Excel SOLVER Function - spreadsheet method for isotherm and kinetics Modeling of Metals Bio sorption in waste water. J Water Sustain 3:223-237

26. Paudyn K, Allision R, Rowe RK, Poland JS (2008) Remediation of hydrocarbon contaminated soil in the Canadian Artic by land farming. Cold
Region Sci Technol 53: 102 - 114 doi.org/https://doi.org/10.1016/j. coldregions.2007.07.006

27. Farahat LA, El-Gendy NS (2007) Comparative kinetic study of different bioremediation process for soil contaminated with petroleum hydrocarbon. J Mater Sci Res 4:269-278

28. Forrester S, Les J, Mike M (2010) An infrared spectroscopic test for total petroleum hydrocarbon (TPH) contamination in soils, $19^{\text {th }}$ World Congress of Soil Science; Soil Solutions for a Changing World

29. Stuart HB (2004) Infrared Spectroscopy, fundamentals and applications. Wiley, University of Technology, Sydney Australia

30. Mohd MB, Deepak K, Kamini N, Shukla RN, Mohammad Y (2011) Mycoremediation of hydrocarbon contaminated soil-FTIR based analysis. World Sci J 15(11):1547-1552

31. Pavia DL, Lampman GM, Kriz GS, Vyan JR (2009) Introduction to Spectroscopy, 4th edn. Brooks/Cole, Belmont

32. Stevenson FJ (1994) Humus chemistry: genesis, composition and reactions, 2nd edn. Wiley, New York

33. Czurak-Dainard M (2005) The long term impact of manure application on soil microbial properties and nutrient cycling in Manitoba soils. M.sc Dissertation University of MB, Winnipeg

34. Alkatib MA, Alam MDZ, Muyibi SA (2011) An Isolated bacteria consortium for crude oil degradation. African J Biotechnol 10:18763-18767

35. Roling WFM, Milner MG, Jones DM (2002) Robust hydrocarbon degradation and dynamics of bacterial communities during nutrient enhanced oil spill bioremediation. Appl Environ Microbiol 68:5537-5548

36. Santisi S, Capello S, Catalfamo M, Mancini G, Hassanshahian M, Genovese L, Guiuliano L, Yakmov MM (2015) Biodegradation of crude oil by individual bacterial strain and mixed bacterial consortium. Braz J Microbiol 42:377-387

37. Hamzah A, Siti N, Md S, Sukiman S (2014) Enhancing biodegradation of crude oil in soil using fertilizer and empty fruit bunch of oil palm. Sain Malaysiana 43:1327-1332

38. Walworth J, Andrew P, Snape I, Rayner J, Feguson S, Harvey P (2007) Nitrogen requirements for maximizing petroleum bioremediation in a subAntarctic soil. Cold Region Sci Technol 48:84-91

39. Brock TD, Madigan MT, Martinko JM, Parker J (1994) Biology of microorganism pp 909, 7th edn. Prentice Hall, New Jersey

40. Vieira FCS, Nahas E, (2005) Comparisons of microbial numbers in soil by using various culture media and temperatures. J Microbiol Res 160: 197 202 doi .org/https://doi.org/10.1016/j.micres.2005.01.004

41. Critter SAM, Freitas SS, Airoldi C (2002) Comparisons between microorganisms counting and calorimetric method applied to tropical soil. Thermochim Acta 394:133-144

42. Muftah HE, Shaheen A, Al-Muhtaseb, Makhlouf S (2009) Biodegradation of phenol by Pseudomonas Putida immobilized in polyvinyl alcohol (PVA) gel, J Hazard Mater 164: 720 - 725 doi.org/https://doi.org/10.1016/j.jhazmat. 2008.08.059

43. Zappi ME, Rogers BA, Teeter Cl, Gunnison D, Bajpai R (1996) Bio slurry treatment of soil with low concentration of total petroleum hydrocarbons. J Hazard Mater 49:1-12

44. Mihial DJ, Viraraghavan T, Jin YC (2006) Bioremediation of petroleum contaminated soil using composting. Waste Manage J 10:108-115

45. Mohsen S, Majid F, Jan, HC (2013) Chemometric assessment of Enhanced bioremediation of oil contaminated soils, J Hazard Mater 254 - 255: 2372381, doi.org/10.1016/j.jhazmat.2013.03.004

46. Nilanjana D, Preethy C (2011) Microbial degradation of petroleum hydrocarbon contaminant: An overview. Biotechnol Res Int:1-13. https://doi. org/10.4061/2011/941810

47. Anders J, Haller H (2014) Sustainability aspect of in-situ bioremediation of polluted soil in developing countries and remote region. INTECH Chapt:2. https://doi.org/10.5772/57315

48. Jorgensen KS, Puustinen J, Suortti AM (2000) Bioremediation of petroleum hydrocarbon contaminated soil by composting bio-pile. Environ Pollut 107: $245-254$

\section{Publisher's Note}

Springer Nature remains neutral with regard to jurisdictional claims in published maps and institutional affiliations. 